\title{
Repercussion of the Education Policy of Special Education in the Portuguese Educational System
}

\author{
Orlando Silvestre Fragata \\ Universidade Fernando Pessoa, Porto, Portugal
}

\begin{abstract}
This paper is a result of previous investigations, which occurred mainly in the classroom and in the perspective of its actors. Some disarticulation related to educational policies are detected, which conditioned the performance of school leadership and teachers. So, in this second stage, we decided to conduct an investigation that examined the contribution of the democracy regime of the portuguese educational policies in the field of special education for the period between 1973 and 2004. The main questions to investigate are as following: - Which contribution is provided by the Constitution of the Portuguese Republic regarding Special Education?

- What does the Base Law of Educational System regulate regarding Special Education?

- Which were the education policies of the governments relatively to Special Education?

The methodological strategy is based on the technique of 'Case Study' with qualitative nature.
\end{abstract}

\section{Introduction}

Portugal has invested in measures of educational policy that have been taking two fundamental points: 1) the effectiveness and improving education; and 2) a reduction in school dropout and failure rates, and the right of education for everyone [5], [7].

The special education in Portugal, like other European countries, has moved forwards and backwards. Any diachronic analysis of special education in Portugal can only be performed and interpreted from the global system context of education, usually designed for a "normal" pattern.

This is characterized by a lack of resources and scarce permeability to proposals from countries with which Portugal habitually identifies. The special education process in Portugal follows the same steps as those countries [6]. In this context, we can speak of a first phase commonly referred to as the "era of the institutions", which covers the period from the second half of the $19^{\text {th }}$ century and early $20^{\text {th }}$ century, characterized by the creation of historical special education centers. Just as the rest of Europe, the only assistance character of the first phase of this stage becomes education during the First Republic (1910), which, ideologically imbued with the ideals of the French Revolution, sees the education as the biggest concern of political power [4].

Despite these changes, the Special Education remains static and is transmitted most often in residential schools, far away from the families of origin, while others are in special classes located within the regular schools. Special education behaves like a subsystem inside - but marginally - the general education system.

The $60 \mathrm{~s}$ are the stage of consolidation and expansion of these specific centers. During this period, highlights the official and public intervention conducted by the Ministry of Social Affairs, mainly focused on the creation of centers and conducting training programs for professionals. At this stage, a particular center deserves special attention. The Children's Center Hellen Keller for children with blindness, which started in 1965 with the first integration experience welcoming in their classes, at the same time blind, visually impaired and normal vision children. Some of his students continued their integration in the preparatory and secondary schools, where at that time still was in place the Popular Education Plan Pires de Lima, published by DecreeLaw No. 38968 of October 27, 1952. This opens the door to the last and current phase [4].

\section{Theoretical context}

During the $\mathrm{X}$ Constitutional Government, a minority government and the first of the three executives of Prime Minister Cavaco Silva, that was outlined some of the major fundamental reforms. In the field of education, João de Deus Pinheiro [Minister of Education] launches the biggest reform of the III Republic, with the Base Law of Educational System [12].

The report of Iberian-American States Organization (2003) on Portugal states that the definition of the present educational system (19861997) begins with the publication, in 1986, of the Base Law of Educational System. The right to education and culture for all children is included in this diploma: the nine years of compulsory education are extended; all young people are guaranteed 
training for working life; the right to a fair and effective equality of opportunity; the freedom to learn and teach; the training of young people and adults who abandon the system (recurrent education); and the educational improvement of the entire population. (p. 26)
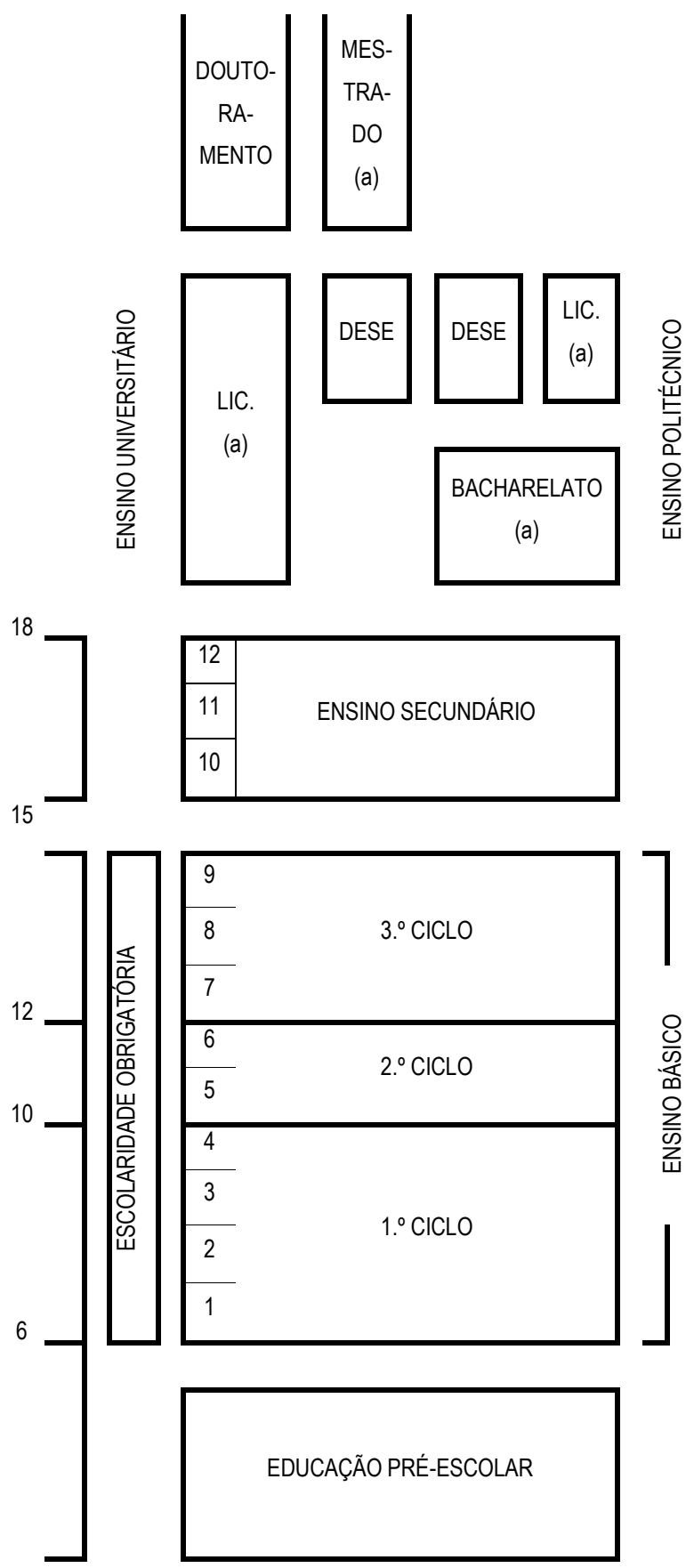

(a) Variable duration

Figure 1. General organizational chart of school and pre-school education (adapted [11])

However, the great innovation of the Base Law of Educational System consisted in the reorganization of the educational system through its subdivision in pre-school, school and out-of-school education.

In this context, the general organization of the educational system contemplates several fundamental aspects that provide an overview of the system. However, we are going to look only at the formal structure, the organizational structure.

The education system, in Law No. 46/86, of October 14, (law that created a new organization of the educational system), includes pre-school education, school education and out-of-school education (article 4, Point 1).

Pre-school education is intended for children between the ages of 3 and entry into compulsory schooling, which is optional.

The school education contains basic, secondary and higher education, integrates special modalities and includes leisure activities (Article 4, point 3). The basic education, which corresponds to compulsory schooling, takes place over nine years, from six to fifteen years of age, and comprises three sequential cycles: the first four-years cycle; the second, two-years cycle; and the third, three-years cycle (Article 8 (1)).

According to Telo [12], Roberto Carneiro proved as one of Cavaco Silva's ministers with more capacity for fulfillment and imagination, which implements the Base Law of Educational System, in which a significant effort is made to apply this concept [universal and free application of compulsory education], with major investments that involve the construction or renovation of some 400 schools and the extension of pre-school education." [12].

Based on the analysis of the Base Law of Educational System, published by Law No. 46/86, of October 14, we verified the existence of new assumptions that determine aspects such as universality, compulsion and gratuitousness, duration of basic education (nine years).

The decades 70-90 meant the establishment of educational integration. The major policy change of April 25, 1974, was a decisive step for equality before the law and the right of everyone to education. However the article 74 of the Constitution of April 2, 1976, consigns that everyone has the right to education, guaranteed the right to equal opportunities, access and school success, the same time as promotes and supports the special education for 'disabled people'. But, as in other countries, it took several years for the legislative development.

The Law of the Education, 1986, again recalls the already established right to ensure that children with special educational needs, with physical and mental disabilities explicitly derived from deficiencies, the appropriate conditions for the full development of their faculties. And one more time it was necessary to wait almost five years, the legislative development 
needed to enforce the rights originally established. Decree-Law No. 35/90, of 25 January, establishes for the first time that students with special educational needs resulting from physical or mental disabilities, are subject to fulfilment of compulsory education and cannot be exempted from the frequency.

It is in this educational context related to special education which converges a fundamental aspect as are the education policies related to diversity of students. The promotion and development of educational policies based on the right of all pupils to equity and quality education will undoubtedly to achieve greater social cohesion.

These aspects highlight the importance and urgency of policy development to promote inclusive education in Portugal. Thus, it was intended to go with a different look, understand and deepen knowledge of the Portuguese educational policy, with a focus on Special Education, and especially tried to meet a common guideline and transverse by the successive post governments Revolution of 25 April 1974 to the early twenty-first century, namely:

- $\quad$ in the Portuguese Constitution of 1976 and in its several revisions, 1982, 1989, 1992, 1997, 2001 and 2004;

- in the Educational System Base Law of 1986 and the first 1997 review;

- in the programs of the six provisional governments, 1974-1976, and fifteen constitutional governments, 1976-2004;

- in Special Needs Education guidance at the legal regulations.

The period that we elected it is justified to because we want to delimit our study to the last 25 years of the twentieth century, the first of the democratic age after the April 25, 1974. Thus, we defined as landmarks for research: the last government of the New State of the II Republic, led by Professor Marcello Jose das Neves Alves Caetano, during which approved the Law No. 5/73, of 25 July, which defined the bases, which was to reform the education system; and the 15th constitutional government, chaired by José Manuel Barroso, which preceded the second amendment to the Framework Law on Education - Law No. 46/86 of 14 October, as amended by Law No. 115/97, September 19.

Starting from this context, we proposed to answer the following questions:

- Which were the education policies of the several governments relatively to Special Education?

- Which contribution is provide by de Constitution of the Portuguese regarding Special Education?

- What does the Educational System Base Law regulate regarding Special Education?

\section{Methodology and procedures}

Having regard to these questions, the draft of the proposed research had as main objective "Understanding that education policies for Portugal between 1973 and 2004 in the context the Special Education".

To achieve this general objective, we proposed to:

- Describe and analyze the Constitution of the Portuguese Republic, in the framework of Special Education;

- Describe and analyse the Base Law of Educational System, in the framework of Special Education;

- Identify, in government programs, educational policies of several governments for Special Education;

- Identify the great reforms of the Portuguese Educational System and collect the testimonies of some teachers and / or actors with responsibilities in the teaching-learning process, from the perspective of Special Education.

To answer the research problems raised, we opted for a qualitative research design, using as information collection techniques, document analysis and interviews.

In the documental collection performed resorted to the following sources: The Portuguese Constitution of 1976 and its several revisions; the Educational System Base Law of 1986 and its 1997 revision; Programs of the six provisional governments, 1974-1976, and fifteen constitutional governments, 1976-2004; diaries sessions of the National Assembly, the Constituent Assembly and the Assembly of the Republic, during the period of time under analysis, and for the Special Education legal regulations published between 1974 and 2004.

With regard to the documentary analysis, we built two instruments for the collection and analysis of data: a map where we observe the structure of laws and another map where we compare the structure of the laws, with reference to the 'Fundamental Principles' and 'Part I - Fundamental rights and duties" of the Constitution.

Table 1. Study dimensions and analysis of themes

\begin{tabular}{|c|c|}
\hline STUDY DIMENSIONS & ANALYSIS THEMES \\
\hline Conceptual & Republic Constituition \\
\hline Legislative & $\begin{array}{l}\text { Law No. } 5 / 73 \text { and Law No. } \\
46 / 86\end{array}$ \\
\hline Programmatic & Government Programs \\
\hline Speech & The Assembly of the Republic \\
\hline
\end{tabular}


To have a connecting thread in research, we established the "Study dimensions" and "Analysis of issues' presented in Table 1.

\subsection{Target}

With regard to interview, we opted for semistructured interviews, organized in 5 dimensions and 22 items. The data collected through the fifty-nine interviews (Table 2 shows the universe of interviewees), were coded and categorized. This work was carried out using a computer program named NVIVO 9.

Table 2. Target group interviews

\section{Interviews $\left(\mathbf{n}^{\mathbf{0}}\right)$}

\begin{tabular}{|c|c|}
\hline Representatives of the trade union area & 6 \\
\hline Representatives of the parliamentary area & 6 \\
\hline Representatives of the school management area & 12 \\
\hline $\begin{array}{l}\text { Representatives of technical and pedagogical area of } \\
\text { education ministry }\end{array}$ & 5 \\
\hline $\begin{array}{l}\text { Representatives of the teaching area to the level of } \\
\text { coordination of educacional support }\end{array}$ & 8 \\
\hline Representatives of teachers in teaching functions & 22 \\
\hline Total & 59 \\
\hline
\end{tabular}

To validate the content of the interviews, we selected a group of experts composed of five university professors specialists in the field of Educational Diversity and Special Education, 5 university professors specialists in the field of Educational Policy and 4 non-university teachers in the field of Educational Diversity. To the Group experts was explained the technique to be used, the objectives of the study and the importance of their participation in the validation process. For the selection of experts used the procedure "competencia coefficient experta" or "K Coefficient", obtained from the application of the formula: $\mathrm{K}=1 / 2(\mathrm{Kc}+$ $\mathrm{Ka}$ ), where $\mathrm{K}$ is the "coefficient of knowledge" or information that has the expert about the problem presented and $\mathrm{Ka}$ is the "coefficient of argument" or state reasons of the criteria of experts [1].

In our case, the coefficient $\mathrm{K}$ is greater than 0.8 in 12 of 14 selected specialists, what showed very acceptable degree of competence.

The estimates made by the experts were held in successive waves and anonymous, in order to get consensus on an "interactive" quiz.

\section{Discussion}

In order to answer the first question of research, we collected the legal norms that publicized the Constitution of the Portuguese Republic and its revisions. This analysis was made resorting to the publications in the official newspaper - the Diary of the Assembly of the Republic.

We conclude that the Constitution of the Republic adequately foresees and fits the problem of Special Education, creating the conditions to produce, Base Law of Educational System, all subsequent legislation necessary for the proper development of Special Education, from the Base Law of the Republic.

For the second research question, we came to the conclusion that the regulations provided for in the Portuguese Constitution, in the framework of Special Education, took the first steps with the publication of the Basic Law on Education (LBSE). However, considering that the Educational System Base Law was published only in 1986, i.e., 12 years after the April 25, 1974, it seemed appropriate to make some observations about the called Law Veiga Simão (Law No. 5 / 73) approved in 1973 and which remained in force in many ways for a long time, even during the 3rd Republic.

The law No. 5/73, of 25 July, already revealed important concerns, of which include:

- (A) the right to education, advocating and ensuring access to various levels of education (Chapter I, Base II, item a);

- (B) intended to provide suitable conditions for the development of "disabled children and unadapted" and the precocious (Chapter II, Section 3rd, 1st Subsection, Base VI, 1) and

- (C) equality of opportunities for all, effecting a compulsory basic education (Chapter I, II Base, b)) with a duration of eight years (Chapter II, Section 3rd, 1st Subsection, Base VI, 3).

As for the "different children", expressly states that pre-school education has as main objectives, among others, to promote the diagnosis, treatment and guidance of children revealing deficiencies, inadequacies or precocious behavior (Chapter II, Section 2 nd, V Base, 1.) and from other general objectives of basic education is concerned, the need to provide children disabled and unadapted or precocious the most suitable conditions for their development (Chapter II, Section 3rd, 1st Subsection, Base VI, 1).

Finished this parenthesis, then we return to the Basic Law on Education, approved in Parliament unanimously and published by Law No. $46 / 86$ of 14 October.

We highlight the most relevant measure, the importance given to Special Education, to be considered as a special type of school education (Article 16) and noted that for the first time is establish their organization (Article 18). We considered still relevant:

- Universal primary education, compulsory, free and with a duration of nine years (Article 6); 
- Objectives of basic education ensure, for children with specific educational needs, adequate conditions for their development and full use of their capacities (Article 7);

- The integration of special education activities for the students, families, educators and communities (Article 17 - 2);

- The frequency of optional pre-school education, the first level of the inadequacies of screening, disability or precocious behavior intended to promote the direction and guidance of the child (Article 5);

Table 3. Education ministers the temporary government and duration of their mandates

\begin{tabular}{|c|c|c|c|c|c|}
\hline \multirow{2}{*}{$\begin{array}{l}\text { TEMPORARY } \\
\text { GOVERNMENT }\end{array}$} & \multirow{2}{*}{$\begin{array}{c}\text { PRIME } \\
\text { MINISTER }\end{array}$} & \multirow{2}{*}{$\begin{array}{l}\text { MINISTER'S } \\
\text { NAME }\end{array}$} & \multicolumn{2}{|c|}{ THE DATE } & \multirow{2}{*}{$\begin{array}{l}\text { TERMS } \\
\text { OF } \\
\text { OFFICE }\end{array}$} \\
\hline & & & START & END & \\
\hline I & $\begin{array}{l}\text { Adelino } \\
\text { da Palma }\end{array}$ & $\begin{array}{l}\text { Eduardo } \\
\text { Correia }\end{array}$ & $\begin{array}{l}15 / 05 \\
1974\end{array}$ & $\begin{array}{l}17 / 07 \\
1974\end{array}$ & $\begin{array}{c}64 \\
\text { days }\end{array}$ \\
\hline II & $\begin{array}{c}\text { Vasco } \\
\text { Gonçalves }\end{array}$ & $\begin{array}{l}\text { Vitorino } \\
\text { Magalhães } \\
\text { Godinho }\end{array}$ & $\begin{array}{l}17 / 07 \\
1974\end{array}$ & $\begin{array}{l}30 / 09 \\
1974\end{array}$ & $\begin{array}{c}75 \\
\text { days }\end{array}$ \\
\hline \multirow{3}{*}{ III } & \multirow{3}{*}{$\begin{array}{c}\text { Vasco } \\
\text { Gonçalves }\end{array}$} & $\begin{array}{l}\text { Vitorino } \\
\text { Magalhães } \\
\text { Godinho }\end{array}$ & $\begin{array}{c}30 / 09 \\
1974\end{array}$ & $\begin{array}{r}29 / 11 \\
1974\end{array}$ & $\begin{array}{c}61 \\
\text { days }\end{array}$ \\
\hline & & $\begin{array}{c}\text { Vasco } \\
\text { Gonçalves }\end{array}$ & $\begin{array}{c}29 / 11 \\
1974\end{array}$ & $\begin{array}{c}04 / 12 \\
1974\end{array}$ & 5 days \\
\hline & & $\begin{array}{l}\text { Manuel } \\
\text { Rodrigues } \\
\text { Carvalho }\end{array}$ & $\begin{array}{c}04 / 12 \\
1974\end{array}$ & $\begin{array}{l}26 / 03 \\
1975\end{array}$ & $\begin{array}{c}112 \\
\text { days }\end{array}$ \\
\hline IV & $\begin{array}{c}\text { Vasco } \\
\text { Gonçalves }\end{array}$ & $\begin{array}{c}\text { José Emílio } \\
\text { da Silva }\end{array}$ & $\begin{array}{c}26 / 03 \\
1975\end{array}$ & & \multirow{2}{*}{$\begin{array}{c}170 \\
\text { days }\end{array}$} \\
\hline V & $\begin{array}{c}\text { Vasco } \\
\text { Gonçalves }\end{array}$ & $\begin{array}{c}\text { José Emílio } \\
\text { da Silva }\end{array}$ & & $\begin{array}{l}12 / 09 \\
1975 \\
\end{array}$ & \\
\hline VI & $\begin{array}{c}\text { Pinheiro } \\
\text { de } \\
\text { Azevedo }\end{array}$ & Vítor Alves & $\begin{array}{l}19 / 09 \\
1975\end{array}$ & $\begin{array}{r}22 / 07 \\
1976\end{array}$ & $\begin{array}{c}308 \\
\text { days }\end{array}$ \\
\hline
\end{tabular}

- The definition of the scope and objectives of special education (Article 17 - 3), providing for the reduction of the limitations caused by the disability, the development of physical and intellectual capabilities and communication; Assistance in acquiring emotional stability; Support for family, school and social inclusion of disabled children and young people; and preparation for appropriate vocational training and integration into working life;

- It defines the organization of special education (Article 18).

During the period from 1974 to 1976 , we saw the establishment of six provisional governments and six ministers of education took office, as shown in Table 3 , which shows the duration of each term of education ministers, all with the duration less than one year.

After this period of great uncertainty in educational policy, the "Constitutional Governments" started functions, resulting from the Portuguese people's vote in the various legislative elections held. Besides, the President of the Republic considered it advisable to appoint him instead of marking new electoral ballots.
As understood from the reading of Table 4, the 16 Constitutional Governments covering the period of 28 years from 1976 to 2004, took office and held office 17 Ministers of Education, but only two of them have exercised their full term of four years, over a parliamentary term - Roberto Carneiro, in the XI Constitutional Government, and Eduardo Marçal Grilo, in the XIII Constitutional Government.

During the investigation, the speeches made in Parliament were analised, and the crossing with the data obtained from the analysis of the interviews undertaken was done.

Parliament's activity is directly linked to the performance of governance and the exercise of opposition. We will cite here some interventions that we consider to be of interest to the conclusions of this work.

During the $1^{\text {st }}$ Constitutional Government of the Socialist Party, Mr. Narana Coissoró (CDS), criticized the Government Program because "special education did not deserve the Government great commitment"1, and Mr. Gonçalves Sapinho (PPD) stated that the Government Program should include "the creation of special schools for the physically and mentally handicapped and the recovery of children"2.

During the period of governance of the Second Constitutional Government, Mrs. Zita Seabra (PCP) pointed out that - the truly positive action of the deepest spirit of human solidarity of teachers, education technicians, parents and other citizens, who soon after the $25^{\text {th }}$ of April joined forces and created in many parts of the country Cooperatives for Education and Rehabilitation of Handicapped Children, the CERCI. In a project truly worthy of all the attention and support, the CERCI began their work despite the many difficulties they sometimes encountered, which were sometimes very unexpected (...). ${ }^{3}$

Table 4. Education ministers of constitutional governments and duration of their mandates

\begin{tabular}{|c|c|c|c|c|c|}
\hline \multirow{2}{*}{$\begin{array}{l}\text { CONSTITUTIONAL } \\
\text { GOVERNMENT }\end{array}$} & \multirow{2}{*}{$\begin{array}{c}\text { PRIME } \\
\text { MINISTER }\end{array}$} & \multirow{2}{*}{$\begin{array}{l}\text { MINISTER'S } \\
\text { NAME }\end{array}$} & \multicolumn{2}{|c|}{ THE DATE } & \multirow{2}{*}{$\begin{array}{l}\text { TERMS } \\
\text { OF } \\
\text { OFFICE }\end{array}$} \\
\hline & & & START & END & \\
\hline I & $\begin{array}{l}\text { Mário } \\
\text { Soares }\end{array}$ & $\begin{array}{c}\text { Mário } \\
\text { Sottomayor } \\
\text { Cardia }\end{array}$ & $\begin{array}{l}23 / 07 \\
1976\end{array}$ & $\begin{array}{c}09 / 12 \\
1977\end{array}$ & 503 days \\
\hline II & $\begin{array}{l}\text { Mário } \\
\text { Soares }\end{array}$ & $\begin{array}{c}\text { Mário } \\
\text { Sottomayor } \\
\text { Cardia }\end{array}$ & $\begin{array}{l}30 / 01 \\
1978\end{array}$ & $\begin{array}{l}28 / 07 \\
1978\end{array}$ & 182 days \\
\hline III & $\begin{array}{l}\text { Nobre da } \\
\text { Costa }\end{array}$ & $\begin{array}{c}\text { Carlos } \\
\text { Alberto } \\
\text { Lloyd } \\
\text { Braga } \\
\end{array}$ & $\begin{array}{l}29 / 08 \\
1978\end{array}$ & $\begin{array}{l}15 / 09 \\
1978\end{array}$ & 18 days \\
\hline IV & $\begin{array}{l}\text { Mota } \\
\text { Pinto }\end{array}$ & $\begin{array}{c}\text { Luís } \\
\text { Valente de }\end{array}$ & $\begin{array}{l}22 / 11 \\
1978 \\
\end{array}$ & $\begin{array}{l}11 / 06 \\
1979 \\
\end{array}$ & 202 days \\
\hline
\end{tabular}

1 Diary of the Assembly of the Republic No. 20 of August 9, 1976: p. 524.

2 Diary of the Assembly of the Republic No. 21 of August 10, 1976: p. 575.

3 Diary of the Assembly of the Republic No. 26, 25 January 1979, p. 901. 


\begin{tabular}{|c|c|c|c|c|c|}
\hline & & Oliveira & & & \\
\hline V & $\begin{array}{c}\text { M. }^{\mathrm{a}} \\
\text { Lourdes } \\
\text { Pintassilgo }\end{array}$ & $\begin{array}{l}\text { Luís Veiga } \\
\text { da Cunha }\end{array}$ & $\begin{array}{c}01 / 08 \\
1979\end{array}$ & $\begin{array}{l}27 / 12 \\
1979\end{array}$ & 161 days \\
\hline VI & $\begin{array}{c}\text { Francisco } \\
\text { Sá } \\
\text { Carneiro } \\
\end{array}$ & $\begin{array}{l}\text { Vítor } \\
\text { Crespo }\end{array}$ & $\begin{array}{c}03 / 01 \\
1980\end{array}$ & $\begin{array}{c}09 / 12 \\
1980\end{array}$ & 351 days \\
\hline VII & $\begin{array}{c}\text { Francisco } \\
\text { Pinto } \\
\text { Balsemão }\end{array}$ & $\begin{array}{l}\text { Vítor } \\
\text { Crespo }\end{array}$ & $\begin{array}{c}09 / 01 \\
1981\end{array}$ & $\begin{array}{l}14 / 08 \\
1981\end{array}$ & 220 days \\
\hline \multirow{2}{*}{ VIII } & \multirow{2}{*}{$\begin{array}{c}\text { Francisco } \\
\text { Pinto } \\
\text { Balsemão }\end{array}$} & $\begin{array}{c}\text { Vítor } \\
\text { Crespo }\end{array}$ & $\begin{array}{c}04 / 09 \\
1981 \\
\end{array}$ & $\begin{array}{l}12 / 06 \\
1982 \\
\end{array}$ & 285 days \\
\hline & & $\begin{array}{l}\text { Fraústo da } \\
\text { Silva }\end{array}$ & $\begin{array}{l}12 / 06 \\
1982\end{array}$ & $\begin{array}{c}23 / 12 \\
1982\end{array}$ & 194 days \\
\hline \multirow{2}{*}{ IX } & \multirow{2}{*}{$\begin{array}{l}\text { Mário } \\
\text { Soares }\end{array}$} & $\begin{array}{c}\text { Augusto } \\
\text { Seabra }\end{array}$ & $\begin{array}{c}09 / 06 \\
1983 \\
\end{array}$ & $\begin{array}{l}15 / 02 \\
1985\end{array}$ & 770 days \\
\hline & & $\begin{array}{l}\text { João Deus } \\
\text { Pinheiro }\end{array}$ & $\begin{array}{l}15 / 02 \\
1985 \\
\end{array}$ & $\begin{array}{c}06 / 11 \\
1985 \\
\end{array}$ & 265 days \\
\hline $\mathrm{X}$ & $\begin{array}{c}\text { Aníbal } \\
\text { Cavaco } \\
\text { Silva } \\
\end{array}$ & $\begin{array}{l}\text { João Deus } \\
\text { Pinheiro }\end{array}$ & $\begin{array}{l}06 / 11 \\
1985\end{array}$ & $\begin{array}{l}17 / 08 \\
1987\end{array}$ & 651 days \\
\hline XI & $\begin{array}{c}\text { Aníbal } \\
\text { Cavaco } \\
\text { Silva } \\
\end{array}$ & $\begin{array}{l}\text { Roberto } \\
\text { Carneiro }\end{array}$ & $\begin{array}{l}17 / 08 \\
1987\end{array}$ & $\begin{array}{c}31 / 10 \\
1991\end{array}$ & 4 years \\
\hline \multirow{3}{*}{ XII } & \multirow{3}{*}{$\begin{array}{c}\text { Aníbal } \\
\text { Cavaco } \\
\text { Silva }\end{array}$} & $\begin{array}{l}\text { Diamantino } \\
\text { Durão }\end{array}$ & $\begin{array}{l}31 / 10 \\
1991 \\
\end{array}$ & $\begin{array}{l}19 / 03 \\
1992 \\
\end{array}$ & 147 days \\
\hline & & $\begin{array}{c}\text { Couto dos } \\
\text { Santos }\end{array}$ & $\begin{array}{l}19 / 03 \\
1992 \\
\end{array}$ & $\begin{array}{c}07 / 12 \\
1993 \\
\end{array}$ & 629 days \\
\hline & & $\begin{array}{c}\text { Manuela } \\
\text { Ferreira } \\
\text { Leite }\end{array}$ & $\begin{array}{c}07 / 12 \\
1993\end{array}$ & $\begin{array}{c}28 / 10 \\
1995\end{array}$ & 691 days \\
\hline XIII & $\begin{array}{l}\text { António } \\
\text { Guterres }\end{array}$ & $\begin{array}{c}\text { Eduardo } \\
\text { Marçal } \\
\text { Grilo } \\
\end{array}$ & $\begin{array}{l}28 / 10 \\
1995\end{array}$ & $\begin{array}{c}25 / 10 \\
1999\end{array}$ & 4 years \\
\hline \multirow{3}{*}{ XIV } & \multirow{3}{*}{$\begin{array}{l}\text { António } \\
\text { Guterres }\end{array}$} & $\begin{array}{c}\text { Guilherme } \\
\text { d'Oliveira } \\
\text { Martins }\end{array}$ & $\begin{array}{l}25 / 10 \\
1999\end{array}$ & $\begin{array}{l}14 / 09 \\
2000\end{array}$ & 326 days \\
\hline & & $\begin{array}{c}\text { Augusto } \\
\text { Santos } \\
\text { Silva }\end{array}$ & $\begin{array}{l}14 / 09 \\
2000\end{array}$ & $\begin{array}{c}03 / 07 \\
2001\end{array}$ & 293 days \\
\hline & & $\begin{array}{c}\text { Júlio } \\
\text { Pedrosa } \\
\end{array}$ & $\begin{array}{l}03 / 07 \\
2001 \\
\end{array}$ & $\begin{array}{l}06 / 04 \\
2002 \\
\end{array}$ & 279 days \\
\hline XV & $\begin{array}{c}\text { José } \\
\text { Manuel } \\
\text { Durão } \\
\text { Barroso } \\
\end{array}$ & $\begin{array}{l}\text { David } \\
\text { Justino }\end{array}$ & $\begin{array}{l}06 / 04 \\
2002\end{array}$ & $\begin{array}{l}17 / 07 \\
2004\end{array}$ & 834 days \\
\hline
\end{tabular}

Mr. Pedro Rosetta (PSD) accuses the Government that in the draft law of the Plan and Budget for 1979 "so-called special education for the disabled is practically non-existent. Suffice it to say that the MEIC does not even disclose statistical data about it". ${ }^{4}$

In July 1979 the draft Special Education Law, presented by the Portuguese Communist Party (PCP), the Socialist Party (PS) and the Social Democratic Party (PSD) were discussed. On July 18, the draft Law of the Socialist Party was approved, with votes in favor of the PS, CDS and PCP, and PSD abstention.

The V Constitutional Government was marked by the publication of Law No. 66/79 of 4 October, promised by Prime Minister Mário Soares, but which was never regulated.

During the debate on the Program of the IX Constitutional Government, a government with a base of parliamentary support from the Socialist Party and the Social Democratic Party, headed by Prime Minister Mário Soares, Mr. Jorge Lemos, addressing the Government leader, questioned him about the Special Education Law: 4 Diary of the Assembly of the Republic No. 41 of 21 March
1979, p. 1432. "are you going to apply the law or not? One speaks vaguely in special education but there is a law. Will you regulate it? Will you apply it? There is nothing in the program! " 5

Later, on a question-and-answer session with the Government, Mr. Jorge Lemos once again asked the Government: "On the questions of special education, I did not get any response. Will the Minister comply with the law or not?"6. Again he got no answer.

In June 1985, during the general debate on one of the draft the Base Law of Educational System, Mrs. Luísa Cachado (PCP) addressed the PS group and directly accused them: it was the gentlemen who, by making an election campaign, presented in this Chamber the special education law, boycotted by the defunct $\mathrm{AD}$, and which, at the moment, in agreement with the PSD, continue to boycott and not regulate it. On the other hand, it is demagoguery, advertising slogans and electors are the double personality, the farce assumed in this House by many Socialist Party deputies when, faced with the schools, teachers and the real problems they face assume the nonrepresentativeness of the Socialist Party, the nonrepresentation of the Assembly, the nonrepresentation of the majority. I have seen farces of these many, many times over the course of this last academic year and, in the face of the hemicycle and the reality of the majority, of the coalition, the compromises and the disgraceful concessions, the Honorable Members break the simulacra, the commitments and assume a new farce: the farce of the coalition, the farce of giving, the farce of compromise. And this is what teachers and school communities in this country are unaware of, because you do not have the capacity, the manhood, and the honesty to unmask and break the simulacrum with teachers and schools. ${ }^{7}$

The interviewee (E1) considers the approval, in 1986, of the Educational System Base Law, Law $46 / 86$ as one of the most important milestones in this field. It further states that, subsequently, assumes, in my opinion, the approval of Decree-Law No. 319/91 of 23 August 1991, which approved the support scheme for students with special educational needs attending elementary and secondary schools. The publication of Joint Ordinance No. 105/97, 30 May 1997, (...), which approves a new legal framework for educational support, focuses on schools responding to the educational needs of students.

\footnotetext{
${ }^{5}$ Diary of the Assembly of the Republic No. 9 of 24 June 1983, p. 233.

6 Diary of the Assembly of the Republic No. 69 of 31 January 1984, p. 3105.

7 Diary of the Assembly of the Republic No. 94 of 20 June 1985, p. 3498.
} 
For the interviewee (E2) it all starts with the publication of the Constitution of the Portuguese Republic, by enshrining the Principle of Universality and the Principle of Equality, in which all citizens are guaranteed the same social dignity and that everyone is equal before the law. It also consecrates an article to citizens with disabilities, guaranteeing them the enjoyment of all the rights enshrined in the Constitution, and emphasizes the right to equal opportunities for access and school success. And it directly blames the State for a national policy towards the citizen with disability.

Then the Base Law of Educational System, Law 46/86, which contemplates and gives special attention to Special Education, in the chapter on the modalities of school education.

For me, until 2004, the other relevant landmark is the publication by Minister Roberto Carneiro of the decree 319 , which revolutionizes what was being done in the field of Special Education in our schools.

Also interviewed E4, E5, E9 and E10 consider the publication of Decree-Law No. 319/91, of August 23, as a fundamental landmark in the development of educational policy, in the framework of Special Education.

Because of its importance we transcribe some excerpts from the technical report prepared by the National Education Council on the Public Policies of Special Education. Like this: In Portugal, although the 1976 Constitution established the universality of compulsory and free basic education (article 74) and the LBSE of 1986 determines that special education is organized "preferably according to diversified models of integration into regular educational establishments"(art. 18 (1)), the right to education and school integration has only been fully implemented with the abolition of measures to exempt compulsory education for children and young people with disabilities through Decree-Law No. 35/90, of 25 January: "Students with specific educational needs resulting from physical or mental disabilities are subject to compulsory schooling and cannot be exempted from attendance (Article 2 (2)). [3]

It also refers to the publication of Decree-Law No. 319/91 of 23 August, which:

Introduces the concept of special educational needs, based on pedagogical criteria to establish the special educational regime of students with disabilities. Subsequently, Order No. 105/97, of May 30, establishes a new legal framework for educational support, focusing on schools responding to the educational needs of the students, defining the roles of special education teachers and the necessary qualification for the exercise of functions" [3].
The National Board of Education concludes that:

With this diploma, the integration of students with disabilities into the regular school now counts on a set of measures that can support their educational process. In this sense, it reflects a perspective of integrated teaching, focused on the problems of students, using direct support measures to accompany the official curriculum, many of them developed outside the classroom context by support teachers placed in teams of special education. [3]

After these comments, it is consensual to say that, in addition to the importance of the lines outlined in the Constitution of the Portuguese Republic in this matter, it was fundamental to publish the Base Law of Educational System and the following regulations, of which we highlight: Decree-Law No. 35/90 of 25 January; Decree-Law No. 319/91 of 23 August; Joint Order No. 105/97 of 30 May.

The Base Law of Educational System was published halfway through the mandate of the $\mathrm{X}$ Constitutional Government, led by Prime Minister Aníbal Cavaco Silva. In the special case of Special Education, Decree-Law No. 35/90 of 25 January and Decree-Law No. 319/91 of 23 August were published during the validity of the XI Constitutional Government, also led by Prime Minister Aníbal Cavaco Silva. Joint Order No. 105/97 of 30 May was published during the mandate of the XIII Constitutional Government, led by Prime Minister António Guterres (PS).

We verified that, apart from the Base Law of Educational System approved in 1986, during a Government of the PSD, and its discussion began in the Assembly of the Republic during the Government of the PS-PSD Central Block, the two mentioned Decrees were published during the Governments of Prime Minister Aníbal Cavaco Silva (PSD).

It should be noted that these diplomas have something in common - the fact that they were published during the governance of governments that had an absolute majority in parliament and whose terms were fulfilled in full, that is, they lasted the estimated time of four years. It is verified that part of the referred legislation was published during the exercise of Governments of the Social Democratic Party.

It is also important to mention that, in the Parliament, the Portuguese Communist Party (PCP) was the most "restless" and the most discontented with the situation of the Portuguese handicapped, appealing on several occasions to the various governments, pointing out the difficulties that were experienced and presenting various motions for people with disabilities. 
We note the intervention of Mr. Manuel Filipe (PCP) at the session of 13 April 1998 on the difficulties of CERCI (Cooperatives for Education and Rehabilitation of Handicapped Children). He remembered that a year ago, in last March, that a major public awareness campaign was launched for the disabled, which was called "Pirilampo Mágico". It was intended to alert public opinion to the difficulties experienced by special education institutions, the CERCI. He tried to show the validity of his work and it was said that there were disabled children and young people, some thousands, at risk of being left unattended. The "fireflies" and the disks were exhausted. The objectives of the disclosure have been achieved. The "Pirilampo Mágico" campaign was intended to sensitize the organs of sovereignty with direct or indirect responsibility for the problem.

We would also like to point out that although most opinions point to the inclusion of students in so-called 'regular' schools, there are teachers who warn us about the non-functionality of legislation and its non-appropriateness to extreme situations, where solutions to enable students with special educational needs to have adequate support for their situation/disability and, on the other hand, to allow the remaining students in the class not to have their progress conditioned due to the existence, in the same class, other students with serious learning problems.

\section{Some interviews tell about this situation:}

The teacher finds himself confronted with the dilemma of paying attention to that student who has very specific needs and forgetting the other nineteen, or the other way around. And he is managing the situation with the sensibility and the good sense that he is capable and of which despite everything the results are not satisfactory.

Teachers are not given any kind of support. The situation is: "Here you have a student with cerebral palsy" for example and "now get yourself!". This is more or less what happens. It is then up to the teacher to experiment, by trial and error, until he finds the "less bad" solution. (E11)

I feel that our classes have more and more children with big health problems and we have no way to make them evolve. As more and more cost containment reduces the number of technicians and the schools are not able to receive them. (E10)

The educational policy in the area of Special Education is inclusive, which, in addition to reassuring our consciences, has more disadvantages for me than advantages, especially for the students involved who should be at the center of the issue.

In other words, to include in a group, even reduced, a student with significant cognitive difficulties is not good for him, neither for the teacher nor for the other students.

It should be noted, therefore, that these solutions are "politically correct" and that a student with these characteristics, because different, needs a different personalized and individualized teaching that does not make sense in the context of a traditional group/class, even if it is small.

What happens now is to put a student in a reduced class and then give him an hour of individualized support in Portuguese, Mathematics and Foreign Language, which is of no use because in most cases he does not follow class and individualized support is insufficient. (E11)

What has happened, and what we have confirmed on the ground is the economic policy that the various governments have been taking.

I have only witnessed successive financial cuts and the withdrawal of family support, which systematically affects the quality of the education of these students with special educational needs and who often make much of what could be done within their classes, especially with other "normal" students. (E6)

\section{Conclusion}

The Constitution provides for and properly frames the issue of the special education. Thus creating the conditions for producing all the subsequent legislation necessary for the development of Special Education, taking as a starting point the Republic Base Law.

Taking in consideration the importance that the educative system deserves, the Base Law should not have taken so long to be published. Ten years is a long time to recover all structural delay that Portugal suffered in 1974.

On the other hand, we verified that much time was wasted by Parliament in futile discussions, "the effectiveness of the political power was also assessed negatively" [9].

The political interests have been superimposed to the national interest and rarely the Parliament managed to stable consensus to support the governments formed.

In matters of governing laws of education in Portugal, we conclude that both the Law No. 5/73, of 25 July, quite advanced for the time and the portuguese political system of the time, such as Law No. 43/86 of 14 October - the Education Act reflected and perfectly framed the fundamental concerns of the population towards the Special Education.

There is a consensus to say that, besides the importance of the lines drawn in the Portuguese Constitution in this respect, the publication of the Base Law on Education and the regulations that followed and which we highlight were fundamental: 
Decree-Law No. 35 / 90, of 25 January, Decree-Law No. 319/91, of 23 August, and the Joint Order No. 105/97, of 30 May.

The Education Base Law was published in the middle of the mandate of the $\mathrm{X}$ Constitutional Government, headed by Prime Minister Aníbal Cavaco Silva (PSD - Social Democratic Party). In the case of Special Education, Decree-Law No. 35/90, of 25 January, and Decree-Law No. 319/91, of 23 August, they were published during the term of the XI Constitutional Government also headed by Prime Minister Aníbal Cavaco Silva. Joint Order No. 105/97, of 30 May, was published during the term of the XIII Constitutional Government, headed by Prime Minister António Guterres (PS - Socialist Party).

We find that, aside of the Education Base Law approved in 1986 during a government of PSD, with its discussion having started in the Assembly of the Republic during the government of PS-PSD Central Block, the two Decree-law mentioned were published during the governments of Prime Minister Aníbal Cavaco Silva.

To point out that these diplomas, structuring diplomas of Special Education, have one thing in common - the fact that they have been published during the government that had an absolute majority of sustainability in Parliament and whose terms have been met in full, ie have lasted the predicted time of four years. We see that part of that legislation was published during the years of the Social Democratic Party government.

With respect to the programs of the various governments we find that: (i) that political instability hinders the direction of education and, consequently, the definition of any consistent educational policy, particularly in the context of Special Education, and (ii) containing too many promises that were not fulfilled.

It is also important to mention that, in Parliament, the Portuguese Communist Party (PCP) was the "restless" and most nonconformist with the situation of the portuguese handicapped people, interpellating in various occasions the various governments, pointing out the difficulties that they were living and presenting several motions for the problems of handicapped people.

We studied also the main measures under six Provisional Governments and fifteen Constitutional Governments.

Of the proposed measures for each of the 15 governments, we concluded that:

- 7 Governments produced legislation in accordance with the measures proposed;

- 2 Governments produced legislation for $1 / 2$ of the measures proposed;

- 1 Government produced legislation for $2 / 5$ of the measures proposed;
- 2 Governments produced legislation for $1 / 4$ of the measures proposed;

- 2 Governments did not honoured the listed proposals;

- 1 Government did not proposed any action under our study.

But [in relation] to this [represented] political plurality in Parliament, as a rule, has not been correspondence in the solutions found at the level of government, such as the frequency of coalition solutions, since for thirty-four years of democratic governments and except for a period of two years, precisely from 1978 to 1980 , which saw a situation of effective presidential initiative of governments, Portugal had seven years and a few months of coalition governments and twenty-three years of one-party governments. [2] Table 5. Quantification of the measures provided for
Government Programs. ${ }^{8}$

\begin{tabular}{|c|c|c|c|c|}
\hline $\begin{array}{l}\text { Governments / } \\
\text { No. of measures } \\
\text { (Education } \\
\text { Special) }\end{array}$ & 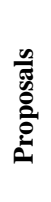 & 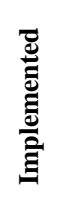 & 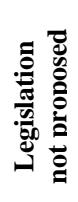 & ㅎํ류. \\
\hline I - PS & 2 & 2 & 3 & 100 \\
\hline II - PS & 8 & 2 & - & 25 \\
\hline III - Ind & 4 & 1 & - & 25 \\
\hline IV - Ind & 1 & 1 & - & 100 \\
\hline V - Ind & - & - & 2 & 0 \\
\hline VI - AD & 2 & 2 & - & 100 \\
\hline VII PSD & 1 & - & - & 0 \\
\hline VIII - PSD & 1 & - & 3 & 0 \\
\hline IX - PS/PSD & 5 & 2 & - & 40 \\
\hline X - PSD & 1 & 1 & 1 & 100 \\
\hline XI - PSD & 1 & 4 & 3 & 100 \\
\hline XII - PSD & 2 & 6 & - & 100 \\
\hline XIII - PS & 2 & 9 & - & 100 \\
\hline XIV - PS & 3 & 2 & - & 66,6 \\
\hline XV - PSD & 1 & 1 & - & 100 \\
\hline
\end{tabular}

This study follows on from two others we did in 1996 and 2006.

The first study, in 1996, sought to study and tried to understand, in terms of the personality of the blind students, how the introduction of informatic skills contributed to the improvement of their self-esteem and their integration path.

The second study, in 2006, carried out an investigation with the objective of understanding how the experience acquired with the informatic skills by the three students with visual impairment

8 PS - Socialist Party; IP - Presidential Initiative; AD Democratic Alliance; PSD - Social Democratic Party. 
was experienced/verbalized and how this favored their integration in the Portuguese society.

After these investigations, we felt the need to carry out a new study in which we could analyse the contribution of the democratic regime to the portuguese educational policies in the field of special education, between 1973 and 2004.

We intend now that its dissemination contribute to a critical reflection on the education policy in the scope of Special Education during this period.

We followed the process of discussion in the Constituent Assembly of the drafting of the Constitution of the Portuguese Republic and, in the Assembly of the Republic, of the discussion leading to the approval of Base Law of Educational System.

We have analyzed in detail the programs of all Governments since 25 April 1974 until 2004 and the respective debates in Parliament.

It seemed to us that, because of the importance that the Educational System deserves, its Base Law should not have taken so long to be published. Ten years is a long time to recover a structural backwardness that Portugal suffered in 1974.

For Pinto [9], "the rule of law is one of the most critical points, where public opinion regarding access to justice and equality before the law is generally quite negative. "

According to Magalhães [8], since the beginning of this century, Portugal is one of the countries of Western Europe whose citizens feel more dissatisfied with the functioning of their democratic regime.

On the other hand, we have seen that much time has been wasted on Parliament by futile discussions. According to Pinto [9], "the effectiveness of political power was also evaluated negatively".

Political interests overcame the national interest and rarely did the parliament achieve stable consensus to support the formed governments.

As for the governments, the situation was also not the best government programs contained too many promises that were not fulfilled, "the lack of trust in politicians and government is the greatest defect of democracy in the country" (p. 5) and, it has been very difficult for the voter to have access to information that allows him to evaluate the actions of the various governments. For Coelho [9],

Any change in the current paradigm will inevitably have to undergo internal changes in these two political forces [PS and PPD / PSD], so that their in-depth study will be justified in the search for avenues for intervention that will allow effective reforms of their to act and position themselves in society, with the aim of giving back to these parties the credibility lost with the erosion of their practical behavior during these years of political democracy, well consubstantiated by several studies of opinion periodically published, but also by the unsatisfactory level of participation electoral process in local or national elections, which may partly confirm this strong distrust of citizens towards the politicians who represent them.

According to the conclusions reached by Pinto [9], in which very clear majority agree with the notion that politicians do not care as something else in addition to their personal interests (...), that politicians do not care about what citizens think and are not responsible for the policies they implement (p. 35), we are of the opinion that the political class should change its paradigm and worry the quality of their political performance and that they should use politics to the benefit of citizens.

It is essential that citizens have accurate information on the political developments in each sector so that they can make their assessments and choices conscientious and informed. According to Pinto [7], "the majority of Portuguese (65\%) feel little or nothing the way democracy works in Portugal today (whereas in 2009 this figure stood at 51\%)."

On the other hand, it is very important that financial resources are channeled into what is really important and that the necessary conditions for the education and monitoring of children and young people with special educational needs are given.

Following our investigation, it is important to propose some future research lines. It is important to know concretely:

- How is processed the allowances granted to the Special Education (considering that the Regulatory Decree No. 19/98, of 14 August, established the arrangements for the allocation of a special education allowance shall regulating introduced by DecreeLaw No. 170 / 80, 29 May)?

- How is processed the financial support of private schools that were given support for students with special educational needs and what were the students that could benefit from it?

- What are the criteria for referral of students with special educational needs or severely disabled to institutions other than the official teaching?

- What are the answers to our research questions applied to the period between 2004 and the present?

\section{References}

[1] Cabero, J. and Barroso, J., La utilización del juicio de experto para la evaluación de tic: el coeficiente de competencia experta, Bordon, 2013, 65 (2), pp. 25-38.

[2] Coelho, M., Os partidos políticos e o recrutamento do pessoal dirigente em Portugal - $O$ caso do PS e do PPD/PSD, Europress, Lisboa, 2014, pp. 32-62. 
[3] CNE, Relatório técnico - Políticas de educação especial. Conselho Nacional de Educação, Lisboa, 2014, pp. 6-8.

[4] Esteves, A. and López Torrijo, M., "La integración educativa en Portugal. Un análisis de la enseñanza obligatoria", Revista Española de Educación Comparada, 11, 2005, pp. 315-356; http://www.uned.es/reec/pdfs/11005/12_esteves.pdf

[5] Fernandes, P., O currículo do ensino básico em Portugal: políticas, perspetivas e desafios. Porto Editora, Porto, 2011.

[6] Fernandes, P., Políticas de educação especial em Portugal: uma análise a partir de um quadro de referência europeu, Maringá, v. 35, n. 2, 2013, pp. 201-211.

[7] Leite, C., O currículo e o multiculturalismo no Sistema Educativo Português, Fundação Calouste Gulbenkian, Lisboa, 2002.

[8] Magalhães, P. (ed.) A qualidade da democracia em Portugal: A perspectiva dos cidadãos, Relatório de estudo, Julho de 2009, p. 6.

[10] Pinto, A., Magalhães, P., Sousa, L. and Gorbunova E., A qualidade da democracia em Portugal: a perspetiva dos cidadãos. Barómetro da qualidade da democracia. Relatório I, Instituto de Ciências Sociais da Universidade de Lisboa, Lisboa, 2011, pp. 5-40.

[11] Pires, E., Lei de bases do sistema educativo. Edições ASA, Rio Tinto, 1987.

[12] Telo, A., História Contemporânea de Portugal - Do 25 de Abril à actualidade. Vol. II. Editorial Presença, Lisboa, 2008, pp. 37-59. 